Air Ministry

Meteorological Office. British Rainfall, 1936: the Seventy-sixth Annual Volume of the British Rainfall Organization. Report on the Distribution of Rain in Space and Time over the British Isles during the Year 1936 as recorded by over 5,500 Observers in Great Britain and Ireland. (M.O. 415.) Pp. xix +292. (London: H.M. Stationery Office, 1937.) 15s. net.

THE seventy-sixth volume of this valuable report on the year's rainfall contains the usual general table of returns from about 5,500 stations in the British Isles. In addition there are sections dealing with such special subjects as droughts, wet spells, duration of rainfall, heavy falls, monthly and seasonal rainfall, evaporation and percolation. From the foreword we learn that the revised system of classification of heavy falls in short periods, described last year in a special article by Mr. E. G. Bilham, has now been introduced. The main effect of the new scheme is to exclude many falls lasting only a few minutes from the 'noteworthy' category. It is also interesting to learn that the arrangements for charting rainfall month by month have now been so greatly improved that the charts prepared for the Monthly Weather Report are accepted, without substantial revision, for publication later in "British Rainfall".

Although the rainfall of 1936 exceeded the normal by nine per cent over England and Wales, there was a marked deficiency in Scotland, amounting to twenty per cent in the Western Highlands. In a special article by Dr. J. Glasspoole, details are given of the unprecedented deficiency of rain in western Scotland during the period November 1935 to June 1936. There is also a valuable article by Mr. L. C. W. Bonacina on the snowfall of the decade 1926-35.

\section{Die Fermente und ihre Wirkungen}

Von Prof. Dr. Carl Oppenheimer. Supplement. Lief. 6 (Band 2, Specieller Teil : Haupt-Teil 13-15). Pp. 783-942. (Den Haag: Dr. W. Junk, 1936.) 10 florins.

THE sixth part of this important supplement deals with the proteinases, in particular with tryptase, pepsinase, chymase (rennet) and also papainase : it follows the plan already indicated. Frequent use of the supplement confirms the opinions already expressed as to its utility and the clarity with which the great amount of information is presented. Sections dealing with the occurrence and distribution of these enzymes may be particularly cited for their completeness and value to the physiological chemist. Naturally, exact directions are given for the preparation of the crystalline enzymes, and one could have wished for some photographs of these crystals in order to bring home to the sceptics their beauty and the magnitude of the achievement.

Prof. Oppenheimer indicates that the completion of the supplement will occupy another year and a half, and he pleads for reprints of papers on enzymes to be sent to him so as to hasten and facilitate this reference to new work, a request which we recommend also to our readers. The address is : Berlin, W.15, Kürfurstendamm 61 .
British Museum (Natural History)

Catalogue of Fossil Cirripedia in the Department of Geology. Vol. 2 : Cretaceous. By Thomas Henry Withers. Pp. xiv $+534+50$ plates. (London : British Museum (Natural History), 1935.) $30 s$.

WHEN the first volume of this Catalogue was published in 1928, the earliest cirriped known was Eolepas from the Rhætic. A much earlier form has since been discovered in the middle Carboniferous of the Donez and Kusnetzk Basins, U.S.S.R. This is a Lepadomorph barnacle, and it shows that the Cirripedia must already have been in existence for a long period, but gives no evidence of the origin of the group. Among many interesting points in phylogeny the author brings forward evidence to show that the three sub-orders of the sessile Cirripedes (the Brachylepadomorpha, the Verrucomorpha and the Balanomorpha) have been derived independently from a pedunculate stock. The Cirripedes show a great development in the Chalk, where nearly a hundred species and varieties are known, but there is an unaccountable imperfection of the record in the Lower Cretaceous deposits, in which only six species have been found; this makes it difficult to connect some of the Jurassic forms with those of the Cretaceous.

The introductory chapters deal with the history of research, phylogeny, ontogeny, distribution, etc. The main part of the work is a systematic account of all the known genera and species of Cretaceous Cirripedes. The reconstructions of some of the more important forms add greatly to the interest of this comprehensive work.

\section{Design :}

a Treatise on the Discovery of Form. By Percy E. Nobbs. Pp. ix +412. (London : Oxford University Press, 1937.) 30s, net.

THIs interesting work fills a gap in æsthetic theory, in so far as the discussion of the subject is developed by a practitioner from fact to principle. Many problems of mechanical, of psychological and of philosophical interest are involved in what seems to be the simple art of design. Illuminating suggestions are offered by the author for the solution of such problems, though he is careful not to commit himself to any particular school of thought. Gestures which seem to be innate for the artist, sueh as the use of scale and proportion, the materialization of ornament, the appreciation of colour and the realization of form, involve a series of elements which the author brings out and discusses with clarity and conviction.

It is in the third part of the book that the mutual process of discovering pure form is described by the consideration of a series of progressively complicated problems of accommodation. It is thus shown that the discovery of pure form is expression, but not art, and that the loss of purity in the form may be compensated for by its artistic elaboration, or by the incorporation with it of extraneous subject-matter by way of adornment. An excellent selection of illustrations gives an added emphasis to the rsthetic views put forward.
'I'. G. 